\title{
Metals in Fishes from Yongshu Island, Southern South China Sea: Human Health Risk Assessment
}

\author{
Zhai Wu, ${ }^{1,2,3}$ Ye Xu, ${ }^{3}$ Minggang Cai, ${ }^{1,2,3,4}$ Sha-Yen Cheng, ${ }^{5}$ \\ Huorong Chen, ${ }^{6}$ Dongren Huang, ${ }^{6}$ Kai Chen, ${ }^{2}$ Yan Lin, ${ }^{1,3}$ Tianyao Li, ${ }^{3}$ \\ Mengyang Liu, ${ }^{1,3}$ Hengxiang Deng, ${ }^{1,3}$ Minjie $\mathrm{Ni}^{2}$ and Hongwei $\mathrm{Ke}^{1,3}$ \\ ${ }^{1}$ Fujian Provincial Key Laboratory for Coastal Ecology and Environmental Studies, Xiamen University, Xiamen 361102, China \\ ${ }^{2}$ Coastal and Ocean Management Institute, Xiamen University, Xiamen 361102, China \\ ${ }^{3}$ College of Ocean and Earth Science, Xiamen University, Xiamen 361102, China \\ ${ }^{4}$ State Key Laboratory of Marine Environmental Science, Xiamen University, Xiamen 361102, China \\ ${ }^{5}$ College of Ocean Science and Resource, National Taiwan Ocean University, Keelung 20224, Taiwan \\ ${ }^{6}$ The Monitoring Center of Marine Environment and Fishery Resources, Fujian Provincial Department of Ocean and Fisheries, \\ Fuzhou 350003, China
}

Correspondence should be addressed to Hongwei Ke; hongwei_ke@xmu.edu.cn

Received 14 July 2017; Revised 5 September 2017; Accepted 19 September 2017; Published 19 October 2017

Academic Editor: Zongming Ren

Copyright (c) 2017 Zhai Wu et al. This is an open access article distributed under the Creative Commons Attribution License, which permits unrestricted use, distribution, and reproduction in any medium, provided the original work is properly cited.

\begin{abstract}
In order to assess the bioaccumulation of metals associated with gender, tissues, and their potential ecological risk, four species of fish were collected from the Yongshu Island in the Southern South China Sea. Metals and stable Pb isotopes in their tissues (muscle, gill, liver, intestine, and ovary) were determined. The concentrations of metals ( $\mathrm{mg} / \mathrm{kg}$, dry weight) in these species were ND-21.60 (Cd), 1.21-4.87 (Cr), 0.42-22.4 (Cu), 1.01-51.8 (Mn), 0.30-3.28 (Ni), 6.04-1.29 × 10 $3(\mathrm{Zn}), 14.89-1.40 \times 10^{3}(\mathrm{Fe})$, and $0.22-3.36(\mathrm{~Pb})$. In general, the liver and intestine absorbed more metals than the other tissues. Metals accumulation can be influenced by gender and feeding behavior and in fact, female fish and dietary exposure are more prone to accumulate metals. In addition, $\mathrm{Pb}$ isotopic ratios indicated that all species had significant biological fractionation, which may not make them good tracers for source identification. The metal concentrations of most samples were lower than the national standard values of the FAO (USA), which suggested that human consumption of these species may not cause health risks. However, since the surrounding areas are developing rapidly, the potential environmental risk of metals will intensify and should receive more attention.
\end{abstract}

\section{Introduction}

Metals, a class of contaminants in aquatic ecosystems, can cause harm to marine organisms and to humans consuming polluted organisms [1-4]. Metals in the marine environments have both natural and anthropogenic sources. The latter, such as smelting, sewage, disposal of fuel burning, and recreational activities, contribute to increasing risks to the aquatic environment due to the rapid development of urban and industrial activities [5]. Via river discharge or atmospheric deposition, which is the most important pathway for the marginal sea, metals enter into aquatic environments and are continually concentrated in food chain through bioaccumulation and biomagnification $[1,6-8]$.
Heavy metals in excessive concentrations present some toxicity to the ecosystem owing to their persistent and nonbiodegradable properties. Exposure to heavy metal contaminants causes chronic DNA damage, degeneration of tissues and the nervous system, and interference with ion homeostasis [7, 9]. For example, $\mathrm{Pb}$ exposure results in anemia and an impact on hemoglobin synthesis $[8,10]$. Cd exposure is related to nephropathy, lung cancer, osteoporosis, abnormal hemopoiesis, and various others [11-13]. The essential metals in excess levels are also toxic to organisms $[14,15]$; for example, a high level of $\mathrm{Cu}$ influences erythrocyte function [16].

Marine organisms, especially fish at the top of the food chain, can assimilate large amounts of contaminants and store 


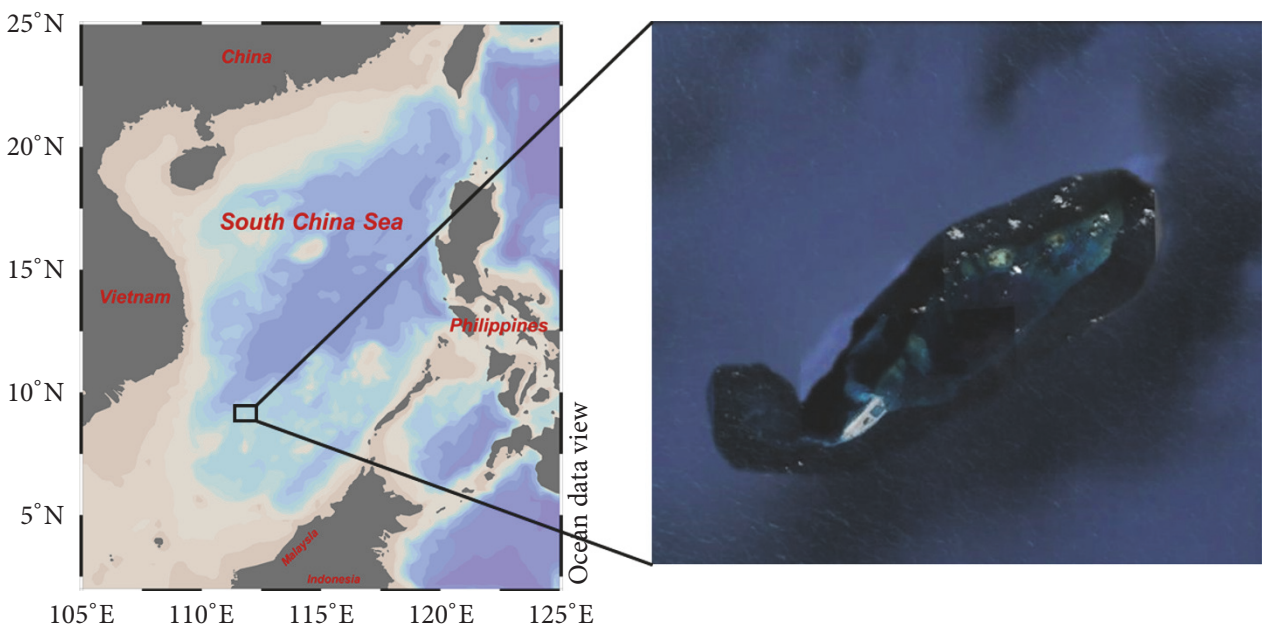

FIGURE 1: The location map of Yongshu Island $\left(9^{\circ} 32^{\prime}-9^{\circ} 42^{\prime} \mathrm{N}, 112^{\circ} 52^{\prime}-113^{\circ} 04^{\prime} \mathrm{E}\right)$, South China Sea. The sampling sites of fishes were distributed outside the island.

them in their tissues $[1,5]$. Thus, fish are widely used as bioindicators of the aquatic environment, indicating environmental contamination $[1,3,17,18]$. The processes of metals accumulation in fish tissues depend on the species, gender, size, metabolic activity of the fish, and the method of metal exposure (e.g., dietary and water exposure) $[1,8,19,20]$. The accumulation of metals in tissues shows enormous variability owing to specific tissue functions, especially metallothioneins (MTs) [21]. MTs, regarded as a biomarker and a cysteine bonding metal, are important for the homeostatic and detoxification of metals [22, 23]. Furthermore, fishes containing high quality protein have great popularity and are consumed in large quantities owing to their benefit to human health [24]. However, fishes contaminated by metals are potentially toxic for humans [25]. In particular, fish can accumulate metals throughout the food chain and generate the toxic effect on human health. Therefore, research into the accumulation of metals in fish tissues is a necessary and good tool to monitor pollution in the environment and to assess the safe threshold for human consumption.

$\mathrm{Pb}$ isotopic ratio is an efficient tool to trace sources and pathways of $\mathrm{Pb}$. The stable isotopes of $\mathrm{Pb}$ are composed of ${ }^{204} \mathrm{~Pb},{ }^{206} \mathrm{~Pb},{ }^{207} \mathrm{~Pb}$, and ${ }^{208} \mathrm{~Pb}$, of which the latter three are products of radiogenic elements. The composition of $\mathrm{Pb}$ isotopes depends on the decay rate and the amount of parent isotopes, and its fractionation does not present in physical and chemical processes [26]. The different sources of $\mathrm{Pb}$ pollution and ore deposits have unique $\mathrm{Pb}$ isotopic ratios, and therefore, many previous studies used isotopic fingerprinting to identify the source of $\mathrm{Pb}$ pollution in aerosols $[27,28]$, sediments [29-31], and organisms [32-34]. However, the study about $\mathrm{Pb}$ isotopic ratios in different fish tissues is scarce so far, because of biological fractionation [32]. Thus, our study set out to identify how much trust can be placed on $\mathrm{Pb}$ isotopic fingerprinting in the source apportionment of fish.

The Nansha Islands are one of the major archipelagos in the South China Sea (SCS), which consist of some islands, islets, cays, and a large number of coral reefs. This archipelago possesses rich natural resources, for example, fisheries, guano, natural gas, and oil reserves, which have the potential to contribute significant economic value to the neighboring countries [35]. Yongshu Island is located on the western edge of the Nansha Islands and is the third largest artificial island $\left(3.06 \mathrm{~km}^{2}\right)$ in this area. Considering the circumstance of the big increase of fishing and culturing activities in the SCS and fast socioeconomic developing of surrounding regions, such intensive human activities on Yongshu Island will discharge pollutants into the local environment and threaten marine organisms [36, 37]. Furthermore, the fishes captured/cultured there will be consumed by the people living in the neighboring countries, and this raises concern about the potential health risks $[38,39]$. As far as we can ascertain, research concerning the concentration and source of metals in fish or other organisms from the waters near Yongshu Island is scarce.

Based on the measured metal concentrations in different tissues (including muscle, gill, liver, intestine, and ovary) of four species fish living there, the objectives of this study included the following: (1) to discuss the metal concentrations in fish tissues; (2) to identify the influence of gender and uptake way on the accumulation of metals in fish; (3) to clarify the influence of $\mathrm{Pb}$ isotope fractionation in different tissues; and (4) to assess the human consumption risk by comparing our results with international guidelines for metals.

\section{Materials and Methods}

2.1. Samples Collection. Yongshu Island (Figure 1), located in the SCS $\left(9^{\circ} 32^{\prime}-9^{\circ} 42^{\prime} \mathrm{N}, 112^{\circ} 52^{\prime}-113^{\circ} 04^{\prime} \mathrm{E}\right)$, is a typical semiclosed atoll with an area of about $110 \mathrm{~km}^{2}$ and a depth of $200 \mathrm{~m}$. The reef is in the shape of a spindle, whose length extends in an NEE-SWW direction for about $25 \mathrm{~km}$, and the width extends in an NW-SE direction for about $6 \mathrm{~km}$.

This research was performed on board of the $\mathrm{R} / \mathrm{V}$ "SHIYAN III" from the South China Sea Institute of Oceanology in August 2013. Twenty-four fish individuals from four species (including Gnathodentex aureolineatus (G. aur), Oxycheilinus diagrammus (O. dia), Melichthys vidua (M. vid), and 
TABLE 1: Detection limit of ICP-MS and analytical results of standard reference material (cod, DORM-4).

\begin{tabular}{lcccc}
\hline Metal & Detection limit $(\mathrm{ng} / \mathrm{L})$ & Measured value $(\mathrm{mg} / \mathrm{kg})$ & Standard value $(\mathrm{mg} / \mathrm{kg})$ & $\mathrm{Recovery}(\%)$ \\
\hline $\mathrm{Cu}$ & 3.20 & 16.6 & $15.9 \pm 0.9$ & $2.4 \pm 0.3$ \\
$\mathrm{~Pb}$ & 1.20 & 2.60 & $52.2 \pm 3.2$ & 104 \\
$\mathrm{Zn}$ & 2.33 & 56.9 & $30.5 \pm 1.6$ & 108 \\
$\mathrm{Cd}$ & 1.20 & 32.3 & $5.2 \pm 0.7$ & 109 \\
$\mathrm{Cr}$ & 12.0 & 5.67 & $279 \pm 14$ & 109 \\
$\mathrm{Mn}$ & 33.2 & 256 & $1.4 \pm 0.2$ & 92 \\
$\mathrm{Ni}$ & 3.20 & 1.55 & $341 \pm 27$ & 114 \\
$\mathrm{Fe}$ & 731 & 363 & & 106 \\
\hline
\end{tabular}

Lutjanus kasmira (L. kas)) were collected by the fishing-line near the island.

2.2. Laboratory Treatment and Instrumental Analysis. The collected samples were washed with deionized water, and their body weights and lengths were recorded. Then the samples were stored in polyethylene bags and kept in a freezer $\left(-20^{\circ} \mathrm{C}\right)$ prior to analysis. Each fish was dissected using a cleaned stainless-steel knife to obtain gill, liver, muscle, heart, and ovary tissues. The G. aur were distinguished for gender by recognition of their genitals. Each sample was freeze-dried and then powdered in an agate mortar.

The metal concentrations in samples of each fish were analyzed based on the USEPA (1990) method with some modifications [46, 47]. Briefly, the powdered samples $(0.200$ $\pm 0.001 \mathrm{~g}$, dry weight) were digested using $2.0 \mathrm{~mL}$ of $\mathrm{HNO}_{3}$ in Teflon, and the solution was heated at $60^{\circ} \mathrm{C}$ until the froth disappeared. Subsequently, the residues were successively digested with $0.5 \mathrm{~mL} \mathrm{H}_{2} \mathrm{O}_{2}, 1.0 \mathrm{~mL} \mathrm{H}_{2} \mathrm{O}_{2}$, and $1.0 \mathrm{~mL} \mathrm{HNO}_{3}$ with $1.5 \mathrm{~mL} \mathrm{H}_{2} \mathrm{O}_{2}$ at $170^{\circ} \mathrm{C}$. After digestion, the solution was diluted to $25 \mathrm{~mL}$ with ultra-pure water. After overnight settling, the solution was transferred into a polyethylene tube and stored at $4^{\circ} \mathrm{C}$. At the same time, to estimate the interference, accuracy, and precision of instructional analysis, the blanks and standard reference material (cod, DORM4) from the National Research Council of Canada were processed along with the samples.

The concentrations of $\mathrm{Zn}$ and Fe were measured using flame atomic absorption spectrometry (FAAS, Thermo Electron M6), while concentrations of $\mathrm{Cu}, \mathrm{Pb}, \mathrm{Cr}, \mathrm{Cd}, \mathrm{Mn}$, and $\mathrm{Ni}$ were determined using inductively coupled plasma-mass spectrometry (ICP-MS, Agilent 7500cx). The samples of fish tissues were also analyzed for their $\mathrm{Pb}$ isotopic composition using ICP-MS. All analytical solutions for $\mathrm{Pb}$ isotope analysis were diluted to about $25 \mu \mathrm{g} / \mathrm{L} \mathrm{Pb}$ with $1 \% \mathrm{HNO}_{3}$ and were determined using ICP-MS.

2.3. $Q A / Q C$. The average recoveries of most metals were around $92-114 \%$, while the recovery of $\mathrm{Pb}$ and $\mathrm{Cr}$ was 108 and $109 \%$ (see Table 1). The quality control standards were used every 10 samples to ensure no contamination and drift from FAAS and ICP-MS analysis.

For $\mathrm{Pb}$ isotopic analysis, a national standard reference material (GBW04425, China) was analyzed for calibration and analytical control. Each sample was determined five times, and the relative standard deviation of each sample was $<0.5 \%$. The average measured ratios of ${ }^{204 / 206} \mathrm{~Pb},{ }^{207 / 206} \mathrm{~Pb}$, and ${ }^{208 / 206} \mathrm{~Pb}$ were $0.1152 \pm 0.000002,0.4692 \pm 0.000041$, and $1.0063 \pm 0.00012$, and the standard values were $0.1156,0.4694$, and 1.0065 .

2.4. Statistical Analysis. Statistical analysis was performed using SPSS 22.0 (International Business Machines Corp.). One-way ANOVA was applied to determine the variation of metals in different fish species and tissues. The relationships among metals were studied using Pearson correlation analysis. In addition, principal component analysis was used to reduce the dimensionality of the data and to further identify the relationships of metals in different fish species.

2.5. Calculation. The provisional maximum tolerable daily intake (PMTDI) is proposed by the WHO/Joint Expert Committee on Food Additives (JECFA), which represents the maximum value of intake in food by humans. According to the report by WHO/JECFA, the PMTDI of $\mathrm{Cu}, \mathrm{Fe}, \mathrm{Mn}, \mathrm{Zn}$, $\mathrm{Cd}, \mathrm{Ni}$, and $\mathrm{Pb}$ are $50 \mu \mathrm{g} /(\mathrm{kg} \mathrm{BW}) /$ day, $4800 \mu \mathrm{g} /(\mathrm{kg} \mathrm{BW}) /$ day, $8 \mu \mathrm{g} /(\mathrm{kg} \mathrm{BW}) /$ day, $100 \mu \mathrm{g} /(\mathrm{kg} \mathrm{BW}) /$ day, $0.5 \mu \mathrm{g} /(\mathrm{kg} \mathrm{BW}) /$ day, $5.0 \mu \mathrm{g} /(\mathrm{kg} \mathrm{BW}) /$ day, and $3.57 \mu \mathrm{g} /(\mathrm{kg} \mathrm{BW}) /$ day [48-50]. The maximum value for human consumption is calculated as follows [17]:

$$
\operatorname{MSC}_{X}=\frac{\left(\mathrm{BW} * \mathrm{PMTDI}_{X}\right)}{C_{X}},
$$

where $C_{X}$ is the concentration of element $X(\mu \mathrm{g} / \mathrm{g}), \mathrm{MSC}_{X}$ is the maximum safe consumption by humans ( $\mathrm{g}$ fish/day), and BW is body weight $(60 \mathrm{~kg})$.

\section{Results and Discussion}

3.1. Variation of Metal Concentrations among the Fish Species. Concentrations of eight metals in G. aur, O. dia, M. vid, and L. kas (whose total length varied from $17.38 \mathrm{~cm}$ to $22.00 \mathrm{~cm}$ ) were analyzed. As shown in Tables 2 and 3, the concentrations of $\mathrm{Cd}, \mathrm{Cr}, \mathrm{Cu}, \mathrm{Mn}, \mathrm{Ni}, \mathrm{Zn}, \mathrm{Fe}$, and $\mathrm{Pb}$ ranged from ND-21.60, 1.21-4.87, 0.42-22.4, 1.01-51.8, $0.30-3.28,6.04-1296.26,14.89-1405.31$, and $0.22-3.36 \mathrm{mg} / \mathrm{kg}$. According to the results of one-way ANOVA, there were significant interspecies variations in $\mathrm{Pb}$ accumulation $(p<$ 0.01) (Figure 2). Fe and $\mathrm{Zn}$ had the highest concentrations 

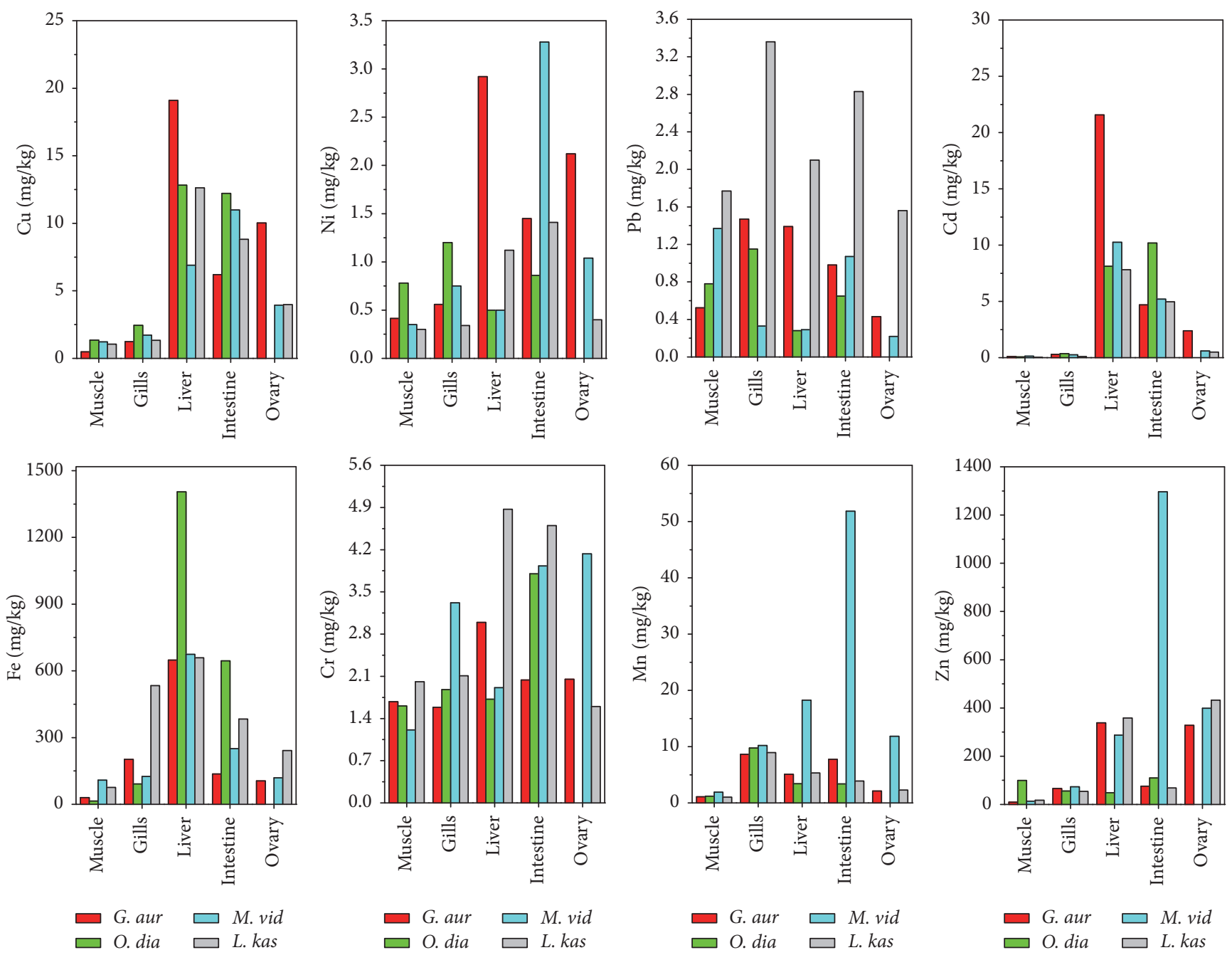

FIgure 2: The distribution of metals in muscle, gill, liver, intestine, and ovary from four fish species.

in different fish species, which was probably because they were essential elements for the organism. For example, $\mathrm{Zn}$ is important for gene proteins (e.g., zinc finger protein), and $\mathrm{Fe}$ is an indispensable element for heme enzymes and ribonucleotide reductase $[19,51,52]$. $\mathrm{Mn}, \mathrm{Cu}, \mathrm{Cr}$, and $\mathrm{Ni}$ are also essential for organisms but showed lower levels probably due to the unavailable high molecular mass complexes and the formation of a less liposolubility organic complex [53]. $\mathrm{Pb}$ and $\mathrm{Cd}$ are nonessential elements for organisms, but the value of $\mathrm{Pb}$ in $L$. kas was generally higher than in the other species, reflecting their diet, growth stage, and the surrounding environment [47].

In general, the concentrations of metals in aquatic organisms significantly varied with different areas and fish species (Table 4). For example, the concentrations of metals in this study area were generally higher than those in the western SCS [39]. Compared with metals concentrations in the Pearl River Estuary, the concentrations of $\mathrm{Mn}, \mathrm{Cr}, \mathrm{Cu}, \mathrm{Ni}$, and $\mathrm{Pb}$ were higher in the Yongshu Island [40]. The concentrations of $\mathrm{Mn}, \mathrm{Cr}, \mathrm{Cu}$, and $\mathrm{Ni}$ in fishes in the south of Brazil were higher than in other regions [41], while the concentrations of Fe and
$\mathrm{Zn}$ in the Yongshu Island were the highest. Concentrations of $\mathrm{Cu}, \mathrm{Ni}$, and $\mathrm{Pb}$ in fishes were lower than in aerosol and sediments in the SCS, while concentration of $\mathrm{Zn}$ in fishes was higher $[5,44]$. The concentrations of $\mathrm{Cd}$ and $\mathrm{Cr}$ in fish were lower than in sediments [44]. These results from other studies indicated that different environments, fish species, and water quality can influence the concentration of metals in fish [54].

3.2. Different Bioaccumulation in a Specific Gender. There was a significant difference of metal concentrations between different genders in G. aur (Table 2), although the male organ was too small to dissect. Generally, the mean concentrations of most metals were higher in female G. aur, which were also found in Lethrinus lentian from the Arabian Gulf and Fundulus heteroclitus from New Jersey and Long Island, USA $[1,55]$.

As for the specific tissues, there were no significant differences between males and females. On the one hand, most metals presented higher concentrations in female muscle and gill; only $\mathrm{Ni}$ in muscle and $\mathrm{Fe}$ and $\mathrm{Cr}$ in the gill were higher in male. This contrasted with the metal distribution 
TABLE 2: Concentrations (mg/kg, dry weight) of eight metals and ${ }^{207 / 206} \mathrm{~Pb}$ and ${ }^{208 / 206} \mathrm{~Pb}$ in female and male Gnathodentex aureolineatus (G. aur).

\begin{tabular}{|c|c|c|c|c|c|c|c|c|c|c|c|c|c|c|}
\hline \multirow{2}{*}{ Gender } & \multirow{2}{*}{ Number } & \multirow{2}{*}{ Total length $(\mathrm{cm})$} & \multirow{2}{*}{ Weight (g) } & \multirow{2}{*}{ Tissues } & \multicolumn{8}{|c|}{ Metals (mg/kg) } & \multirow{2}{*}{${ }^{207 / 206} \mathrm{~Pb}$} & \multirow[t]{2}{*}{${ }^{208 / 206} \mathrm{~Pb}$} \\
\hline & & & & & $\mathrm{Fe}$ & $\mathrm{Mn}$ & $\mathrm{Zn}$ & $\mathrm{Ni}$ & $\mathrm{Cu}$ & $\mathrm{Pb}$ & $\mathrm{Cd}$ & $\mathrm{Cr}$ & & \\
\hline \multirow{5}{*}{ Female } & \multirow{5}{*}{10} & \multirow{5}{*}{$17.38 \pm 0.47$} & \multirow{5}{*}{$72.64 \pm 1.45$} & Muscle & 43.8 & 1.09 & 13.3 & 0.34 & 0.55 & 0.65 & 0.12 & 1.83 & 0.991 & 2.219 \\
\hline & & & & Gill & 146 & 9.27 & 92.6 & 0.58 & 1.49 & 1.94 & 0.29 & 1.51 & 0.982 & 2.194 \\
\hline & & & & Liver & 804 & 4.34 & 555 & 2.86 & 22.4 & 0.82 & 21.6 & 1.66 & 0.979 & 2.188 \\
\hline & & & & Intestine & 157 & 6.89 & 104 & 1.05 & 6.11 & 1.18 & 4.15 & 1.92 & 0.987 & 2.191 \\
\hline & & & & Ovary & 105 & 2.12 & 328 & 2.12 & 10.0 & 0.43 & 2.39 & 2.05 & 1.001 & 2.196 \\
\hline \multirow{4}{*}{ Male } & \multirow{4}{*}{6} & \multirow{4}{*}{$17.67 \pm 0.40$} & \multirow{4}{*}{$70.72 \pm 8.20$} & Muscle & 16.6 & 1.11 & 6.04 & 0.49 & 0.42 & 0.40 & 0.08 & 1.53 & 0.991 & 2.202 \\
\hline & & & & Gill & 258 & 7.98 & 40.3 & 0.54 & 0.98 & 1.00 & ND & 1.66 & 0.974 & 2.188 \\
\hline & & & & Liver & 493 & 5.81 & 122 & 2.98 & 15.8 & 1.96 & 21.55 & 4.33 & 0.996 & 2.214 \\
\hline & & & & Intestine & 115 & 8.60 & 47.5 & 1.85 & 6.30 & 0.78 & 5.25 & 2.16 & 0.982 & 2.182 \\
\hline
\end{tabular}

ND: below the detection limit.

in the intestine, where the male accumulated more metals except $\mathrm{Fe}, \mathrm{Zn}$, and $\mathrm{Pb}$. Concentrations of $\mathrm{Fe}, \mathrm{Zn}$, and $\mathrm{Cu}$ in livers were higher in female, whereas $\mathrm{Mn}, \mathrm{Pb}$, and $\mathrm{Cr}$ were higher in male. On the other hand, certain metals in some tissues showed no difference regarding gender, such as $\mathrm{Ni}$ in the gill and liver, $\mathrm{Cd}$ in the liver, and $\mathrm{Mn}$ in the muscle. The accumulation of metals is influenced mostly by hormonal activities, and besides that, growth rate, diet, and environment also need to be considered $[1,56]$. The female and male fish had different concentrations of steroid hormone, and the highest concentrations were found in the liver. Metals can be combined with steroid hormone and then stored in ovary or sperm to result in the different metal concentrations in each gender [18].

3.3. Accumulation of Metals in Specific Tissues. The maximum concentrations of $\mathrm{Zn}, \mathrm{Mn}$, and Ni were shown in the intestine of M. vid (Figure 2), while those of $\mathrm{Fe}, \mathrm{Cd}$, and $\mathrm{Cr}$ were found, respectively, in the liver of $O$. dia, female G. aur, and L. kas. Fe and Cd had significantly higher concentrations in the liver than in other organs $(p<0.01)$, except in the intestine of $O$. dia $(p<0.05)$. The concentration of $\mathrm{Cu}$ varied significantly with different organs $(p<0.05)$, and a higher concentration was observed in the liver than in the muscle, gill, or ovary. The liver is an important organ for accumulation, metabolism, and detoxification with a large number of MTs, which are regarded as biomarkers and as cysteine bonding metals [22]. The observed high concentrations of metals in the liver were related to the formation of MTs and complexing with enzymes. Therefore, liver of fishes is normally recognized as an indicator of environmental pollution and is used to determine the effect of pollution.

In addition to the liver, the intestine can indicate environmental stress from metals. Figure 2 shows that the intestine was the main organ to accumulate metals, especially in O. dia for Fe $(645.35 \mathrm{mg} / \mathrm{kg})$ and $\mathrm{Cd}(10.19 \mathrm{mg} / \mathrm{kg}) ;$ M. vid for $\mathrm{Mn}$ $(51.83 \mathrm{mg} / \mathrm{kg}), \mathrm{Ni}(3.28 \mathrm{mg} / \mathrm{kg})$, and $\mathrm{Zn}(1296.26 \mathrm{mg} / \mathrm{kg})$; and L. kas for $\mathrm{Cr}(4.60 \mathrm{mg} / \mathrm{kg})$ and $\mathrm{Pb}(2.83 \mathrm{mg} / \mathrm{kg})$. The intestine is a site for dietary exposure with abundant MTs and so dietary metals can be captured by the MTs and accumulated in the intestinal epithelia [20].
Similar to the intestine, the gill is a major organ for metal uptake during water exposure and is the first direct contact with sea water to take in pollutants [57]. Compared with the liver and intestine, the accumulation of metals in the gill was lower. The higher concentrations were present in $O$. dia for $\mathrm{Cu}(2.45 \mathrm{mg} / \mathrm{kg}) ; L$. kas for $\mathrm{Fe}(533.80 \mathrm{mg} / \mathrm{kg})$ and $\mathrm{Pb}$ (3.36 mg/kg); G. aur for Zn (92.62 mg/kg); and M. vid for Mn $(10.21 \mathrm{mg} / \mathrm{kg})$ and $\mathrm{Cd}(0.25 \mathrm{mg} / \mathrm{kg})$. Mn showed a particularly high concentration due its bioavailability to fish [1]. In addition, the gill has the thinnest epithelium so facilitating ion exchange with other tissues. The L. kas accumulated more $\mathrm{Pb}$ in gill than other species, probably because the stress from pollutants influences enzymatic activities and ion exchange. In addition, the high concentration of $\mathrm{Pb}$ will cause the decreasing of enzymatic activity in fishes, and then it makes gill more exposed to contaminant [58].

Some metals, especially $\mathrm{Zn}$ and $\mathrm{Cr}$, were found to accumulate in the ovary and may play an important role in the normal endocrine system of the organism [59]. However, a high concentration of $\mathrm{Zn}$ may result in abnormalities of the gonads in fish [56].

The concentrations of metals stored in muscle were the lowest. For example, concentrations of $\mathrm{Cd}$ in $\mathrm{O}$. dia and L. kas were lower than the detection limit, but $\mathrm{Mn}$ and $\mathrm{Ni}$ were accumulated significantly less in muscle than in the intestine $(p<0.05)$. The reason may be that muscle is not an active tissue to take in nutritive materials compared with liver and gill [60]. However, unlike other metals, $\mathrm{Pb}$ concentration in muscle was not significantly lower than in other tissues, which may be attributed to the environment, species, metabolism activities, and eating habit.

3.4. Comparison between Dietary and Water Exposure. Generally, fish have two primary means of metal exposure: dietary exposure by the intestine and water exposure by the gill [20,61]. As the osmoregulatory tissues of fish, the gill and intestine make first contact with the environment [62].

Most metals ( $\mathrm{Cd}, \mathrm{Cr}, \mathrm{Cu}$, and $\mathrm{Zn}$ ) presented the highest concentrations in the intestine of all fish species (Tables 2 and 3), especially for the intestine in M. vid. On the other hand, $\mathrm{Pb}$ and $\mathrm{Mn}$ showed higher concentrations in the gill of the other 
TABle 3: Concentrations (mg/kg, dry weight) of metals and ${ }^{207 / 206} \mathrm{~Pb}$ and ${ }^{208 / 206} \mathrm{~Pb}$ in muscle, gill, liver, intestine, and ovary in three fish species (O. dia, M. vid, and L. kas).

\begin{tabular}{|c|c|c|c|c|c|c|c|c|c|c|c|c|}
\hline \multirow{2}{*}{ Fish } & \multirow{2}{*}{ Total length $(\mathrm{cm})$} & \multirow{2}{*}{ Tissues } & \multicolumn{8}{|c|}{ Metals (mg/kg) } & \multirow{2}{*}{${ }^{207 / 206} \mathrm{~Pb}$} & \multirow{2}{*}{${ }^{208 / 206} \mathrm{~Pb}$} \\
\hline & & & $\mathrm{Fe}$ & Mn & $\mathrm{Zn}$ & $\mathrm{Ni}$ & $\mathrm{Cu}$ & $\mathrm{Pb}$ & $\mathrm{Cd}$ & $\mathrm{Cr}$ & & \\
\hline \multirow{4}{*}{ Oxycheilinus diagrammus (O. dia) } & \multirow{4}{*}{$22 \pm 2$} & Muscle & 14.9 & 1.19 & 99.4 & 0.78 & 1.35 & 0.78 & 0.06 & 1.61 & 0.995 & 2.182 \\
\hline & & Gill & 91.5 & 9.76 & 55.7 & 1.20 & 2.45 & 1.15 & 0.35 & 1.88 & 0.991 & 2.230 \\
\hline & & Liver & 1405 & 3.40 & 48.8 & 0.50 & 12.8 & 0.28 & 8.12 & 1.72 & 0.986 & 2.216 \\
\hline & & Intestine & 645 & 3.37 & 110 & 0.86 & 12.2 & 0.65 & 10.19 & 3.80 & 0.999 & 2.214 \\
\hline \multirow{5}{*}{ Melichthys vidua (M. vid) } & \multirow{5}{*}{$19.9 \pm 1.4$} & Muscle & 109 & 1.92 & 13.8 & 0.35 & 1.22 & 1.37 & 0.14 & 1.21 & 0.994 & 2.204 \\
\hline & & Gill & 125 & 10.21 & 73.3 & 0.75 & 1.72 & 0.33 & 0.25 & 3.32 & 0.980 & 2.164 \\
\hline & & Liver & 674 & 18.27 & 287 & 0.50 & 6.89 & 0.29 & 10.2 & 1.91 & 0.981 & 2.191 \\
\hline & & Intestine & 250 & 51.83 & 1296 & 3.28 & 11.0 & 1.07 & 5.21 & 3.93 & 0.994 & 2.208 \\
\hline & & Ovary & 119 & 11.83 & 399 & 1.04 & 3.94 & 0.22 & 0.60 & 4.13 & 1.000 & 2.219 \\
\hline \multirow{5}{*}{ Lutjanus kasmira (L. kas) } & \multirow{5}{*}{$19.2 \pm 1.2$} & Muscle & 75.9 & 1.01 & 17.5 & 0.30 & 1.05 & 1.77 & 0.03 & 2.01 & 0.990 & 2.208 \\
\hline & & Gill & 534 & 8.95 & 54.6 & 0.34 & 1.33 & 3.36 & 0.10 & 2.11 & 0.987 & 2.197 \\
\hline & & Liver & 659 & 5.34 & 358 & 1.12 & 12.6 & 2.10 & 7.81 & 4.87 & 0.998 & 2.207 \\
\hline & & Intestine & 384 & 3.89 & 68.3 & 1.41 & 8.82 & 2.83 & 4.96 & 4.60 & 0.988 & 2.205 \\
\hline & & Ovary & 242 & 2.29 & 432 & 0.40 & 3.98 & 1.56 & 0.49 & 1.60 & 0.984 & 2.202 \\
\hline
\end{tabular}

Note. (1) The data relating to G. aur is set out in Table 2; and (2) the ovaries of female G. aur and O. dia were too small to obtain data.

three species, and high concentrations of $\mathrm{Ni}$ in $\mathrm{O}$. dia and $\mathrm{Fe}$ in L. kas were also present in the gill. By way of conclusion, diet is the primary source of metal contamination in fishes, as noted in Mullus barbarous and Salmo trutta [20,63]. The intestine has a large number of natural resistance associated macrophage proteins, and one of them is DMT1, which is related to the transportation of metals and could contribute to the interactions of $\mathrm{Cu}$ and $\mathrm{Zn}$ in the intestine [64]. On the other hand, metals may compete against each other to bond with DMT1; for example, $\mathrm{Ni}$ and $\mathrm{Pb}$ inhibit the absorption of intestinal $\mathrm{Fe}$, and $\mathrm{Cd}$ competes with $\mathrm{Fe}^{2+}$ for uptake in the fish intestine [65].

3.5. Relationship between Metals in Fish Species. Significant positive relationships were found among $\mathrm{Zn}, \mathrm{Mn}$, and $\mathrm{Ni}$ $(p<0.01)$ as well as $\mathrm{Cd}$ and $\mathrm{Cu}(p<0.01)$ in different tissues (Table 5). The concentrations of $\mathrm{Cr}$ and $\mathrm{Zn}$ also showed a significant positive relationship $(p<0.05)$.

The data concerning metals in different fish species were extracted to three principal components (PCs), and these components accounted for $72.785 \%$ of the total variance (Table 6). PC1 made up 35.323\% of the total variance, which was composed of $\mathrm{Mn}, \mathrm{Zn}$, and $\mathrm{Ni}$, representing bioavailability and essential elements for the marine organism. $\mathrm{Cu}$ and $\mathrm{Cd}$ had the highest loading on PC2 and explained 23.633\% of the total variance. These two metals can both form stable chelates (e.g., tetrahedral MT) with some protein molecules and further affect the metabolic process of the organism $[1,19$, 66]. Fe and $\mathrm{Pb}$ (both of which may interact with hemoglobin) were separated from the other metals to constitute PC3. The high concentration of $\mathrm{Pb}$ results in anemia, inhibits some enzymes, and chelates with $\mathrm{Fe}[34,67]$.

3.6. Application of $\mathrm{Pb}$ Isotopes in Biological Fractionation. The $\mathrm{Pb}$ concentrations in most fish species were lower than $2 \mathrm{mg} / \mathrm{kg}$ (Figures 3(c) and 3(d)), except L. kas. All tissues of
L. kas showed a homogeneous distribution of ${ }^{208 / 206} \mathrm{~Pb}$ with a mean of 2.204 , while its ${ }^{207 / 206} \mathrm{~Pb}$ varied from 0.984 to 0.998 and the maximum value was detected in the liver. In G. aur, ${ }^{207 / 206} \mathrm{~Pb}$ decreased with increasing $\mathrm{Pb}$ concentration. The gill and liver had low $\mathrm{Pb}$ concentrations and ratios, while those in the intestine and muscle were both high. The ovary of $M$. vid which had a low $\mathrm{Pb}$ concentration, however, had higher ${ }^{207 / 206} \mathrm{~Pb}$ ratios than the other tissues.

There was a large variation of $\mathrm{Pb}$ isotopic ratios among different tissues (Figure 3(b)), which was similar to other mammal or birds [32]. The highest concentration of $\mathrm{Pb}$ measured in the gill suggested that the fish can accumulate $\mathrm{Pb}$ from water primarily through its gill [68]. Compared with the $\mathrm{Pb}$ isotopic ratio in their surrounding environments (Figure 3(a)), the studied fish tended to accumulate $\mathrm{Pb}$ with higher atom weight, which resulted in higher ratios in different tissues. These results suggested that biological fractionation was present in these fish species.

3.7. Human Consumption Risk Assessment. Metals can enter the human body by consumption of the muscle of fishes, and so the metal concentrations in the muscle can be used as a tool to assess human health risks [3]. The Food and Agriculture Organization (FAO) and the World Health Organization (WHO) propose the permissible limit of metals to evaluate human risk from food consumption, and the values are as follows: $100 \mathrm{mg} / \mathrm{kg}$ for Fe, $0.5 \mathrm{mg} / \mathrm{kg}$ for $\mathrm{Mn}, 2.0 \mathrm{mg} / \mathrm{kg}$ for $\mathrm{Pb}$, $0.15 \mathrm{mg} / \mathrm{kg}$ for $\mathrm{Cr}, 10.0 \mathrm{mg} / \mathrm{kg}$ for $\mathrm{Cu}, 50 \mathrm{mg} / \mathrm{kg}$ for $\mathrm{Zn}$, and $0.5 \mathrm{mg} / \mathrm{kg}$ for $\mathrm{Cd}[48,49]$. Cr and Mn concentrations in all fish species in our study exceeded the permissible limit values. The values of $\mathrm{Zn}$ in $\mathrm{O}$. dia and $\mathrm{Fe}$ in $M$. vid were also above the FAO/WHO guidelines.

The results of $\mathrm{MSC}_{X}$ are listed in Table 7. According to an FAO report, per capita fish consumption in China is $104 \mathrm{~g} /$ day [69]. The MSC values of metals in female G. aur were higher than those in male G. aur, except for Ni. The O. dia suffered 


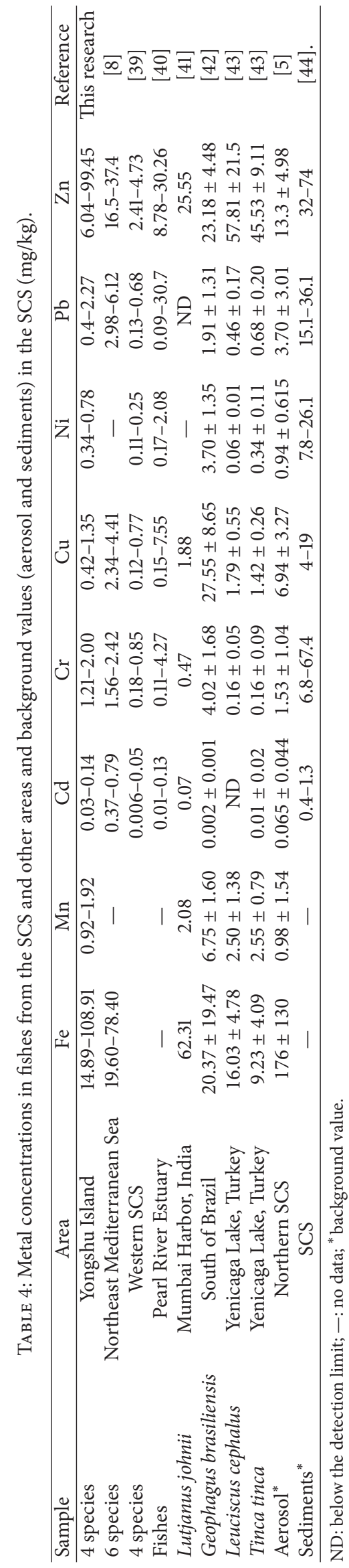


TABLE 5: Pearson correlation coefficients between metals in different species.

\begin{tabular}{|c|c|c|c|c|c|c|c|c|}
\hline & $\mathrm{Fe}$ & $\mathrm{Mn}$ & $\mathrm{Zn}$ & $\mathrm{Ni}$ & $\mathrm{Cu}$ & $\mathrm{Pb}$ & $\mathrm{Cd}$ & $\mathrm{Cr}$ \\
\hline $\mathrm{Fe}$ & 1 & 0.023 & 0.034 & 0.051 & 0.141 & 0.039 & 0.316 & 0.164 \\
\hline Mn & & 1 & $0.795^{* *}$ & $0.568^{* *}$ & 0 & -0.100 & 0.013 & 0.309 \\
\hline $\mathrm{Zn}$ & & & 1 & $0.622^{* *}$ & 0.239 & -0.150 & 0.218 & $0.447^{*}$ \\
\hline $\mathrm{Ni}$ & & & & 1 & 0.091 & -0.004 & 0.211 & 0.349 \\
\hline $\mathrm{Cu}$ & & & & & 1 & -0.211 & $0.934^{* *}$ & 0.133 \\
\hline $\mathrm{Pb}$ & & & & & & 1 & -0.188 & 0.006 \\
\hline $\mathrm{Cd}$ & & & & & & & 1 & 0.148 \\
\hline $\mathrm{Cr}$ & & & & & & & & 1 \\
\hline
\end{tabular}

TABLE 6: Principal component analysis (PCA) of metals in the four fish tissues.

\begin{tabular}{lccc}
\hline & & Components & \\
& $1(35.323 \%)$ & $2(23.633 \%)$ & $3(13.829 \%)$ \\
\hline $\mathrm{Fe}$ & 0.232 & 0.318 & 0.664 \\
$\mathrm{Mn}$ & 0.718 & -0.515 & -0.113 \\
$\mathrm{Zn}$ & 0.861 & -0.324 & -0.115 \\
$\mathrm{Ni}$ & 0.726 & -0.333 & 0.058 \\
$\mathrm{Cu}$ & 0.527 & 0.782 & -0.116 \\
$\mathrm{~Pb}$ & -0.225 & -0.224 & 0.716 \\
$\mathrm{Cd}$ & 0.572 & 0.787 & 0.025 \\
$\mathrm{Cr}$ & 0.576 & -0.167 & 0.332 \\
\hline
\end{tabular}

TABLE 7: The maximum safe consumption of metals $\left(\mathrm{MSC}_{\mathrm{A}}\right)$ in the four fish species ( $\mathrm{g}$ fish/day).

\begin{tabular}{lccccccc}
\hline & $\mathrm{Fe}$ & $\mathrm{Mn}$ & $\mathrm{Zn}$ & $\mathrm{Ni}$ & $\mathrm{Cu}$ & $\mathrm{Pb}$ & $\mathrm{Cd}$ \\
\hline G. aur $(\mathrm{F})$ & 6575.34 & 440.38 & 450.45 & 882.35 & 5454.55 & 329.54 & 250.00 \\
G. aur $(\mathrm{M})$ & 17318.10 & 432.43 & 993.38 & 612.24 & 7142.86 & 535.50 & 375.00 \\
G. aur $(\mathrm{A})$ & 9530.11 & 436.36 & 619.83 & 714.29 & 6122.45 & 404.15 & 300.00 \\
O. dia & 19341.84 & 403.36 & 60.33 & 384.62 & 2222.22 & 274.62 & 500.00 \\
M. vid & 2644.39 & 250.00 & 433.53 & 857.14 & 2459.02 & 159.02 & 214.29 \\
L. kas & 3795.97 & 475.25 & 343.45 & 1000.00 & 2857.14 & 121.02 & 1000.00 \\
\hline
\end{tabular}

F: female; M: male; A: average.

severe $\mathrm{Zn}$ pollution and would pose danger to human health, because the $\mathrm{MSC}_{\mathrm{Zn}}$ in $\mathrm{O}$. dia was below $100 \mathrm{~g}$ fish/day. This meant that, in order to avoid the negative effect of $\mathrm{Zn}$, per capita fish consumption of $O$. dia from Yongshu Island should be below $60.33 \mathrm{~g} /$ day. Both $\mathrm{MSC}_{\mathrm{Fe}}$ and $\mathrm{MSC}_{\mathrm{Cu}}$ in all fish species exceeded 1000, especially for Fe in O. dia, which had the highest value of MSC. This meant that $\mathrm{Fe}$ and $\mathrm{Cu}$ are likely to cause less harm to human health by fish consumption. The lowest values of MSC in G. aur, M. vid, and L. kas were $300 \mathrm{~g} /$ day for $\mathrm{Cd}, 159.02 \mathrm{~g} /$ day for $\mathrm{Pb}$, and $121.02 \mathrm{~g} /$ day for $\mathrm{Pb}$, all higher than the per capita fish consumption.

According to the results from the assessment, $\mathrm{MSC}_{\mathrm{Zn}}$ and $\mathrm{MSC}_{\mathrm{Pb}}$ were lower than the values of other metals MSC, which indicated that $\mathrm{Zn}$ and $\mathrm{Pb}$ may cause more harm to human by fish consumption. The muscle of O. dia, M. vid, and L. kas tended to accumulate higher concentrations of $\mathrm{Zn}$ and $\mathrm{Pb}$. These results indicated that the safe consumption of O. dia, M. vid, and L. kas should be below the MSC, while the concentrations of metals in G. aur were safe for consumption.

\section{Conclusion}

This study presented the variations of metals in different tissues of four species of fish. Fe and $\mathrm{Zn}$ showed the highest concentrations in all species, while the value of $\mathrm{Pb}$ in $L$. kas was generally higher than in the other species $(p<0.01)$. The gender difference significantly impacted on the distribution of metals; for example, the concentrations of metals in female $G$. aur were higher than those in the male. More metals were accumulated in the intestine and liver, compared with other tissues. In addition, dietary exposure was more important than water exposure for food uptake and metal accumulation in fish from Yongshu Island waters.

According to the results of statistical analysis, $\mathrm{Zn}, \mathrm{Mn}$, and $\mathrm{Ni}$ acted as essential metals that showed a significant positive relationship $(p<0.01)$. Cu and $\mathrm{Cd}$ also had a positive correlation and made up PC2, which competed to form stable chelates. Fe and $\mathrm{Pb}$ constituted PC3, and both interacted with hemoglobin. 


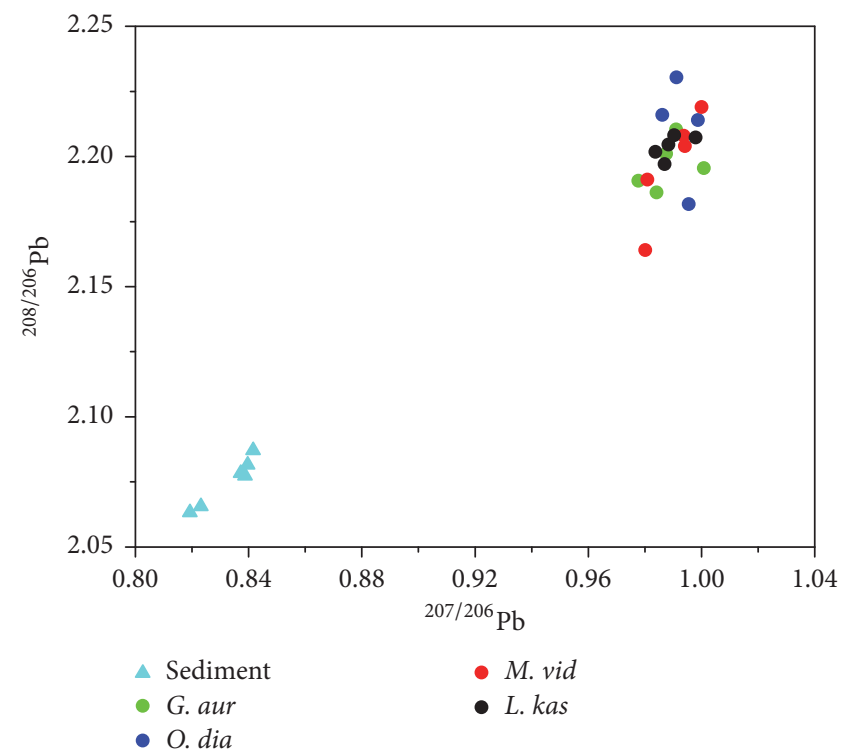

(a)

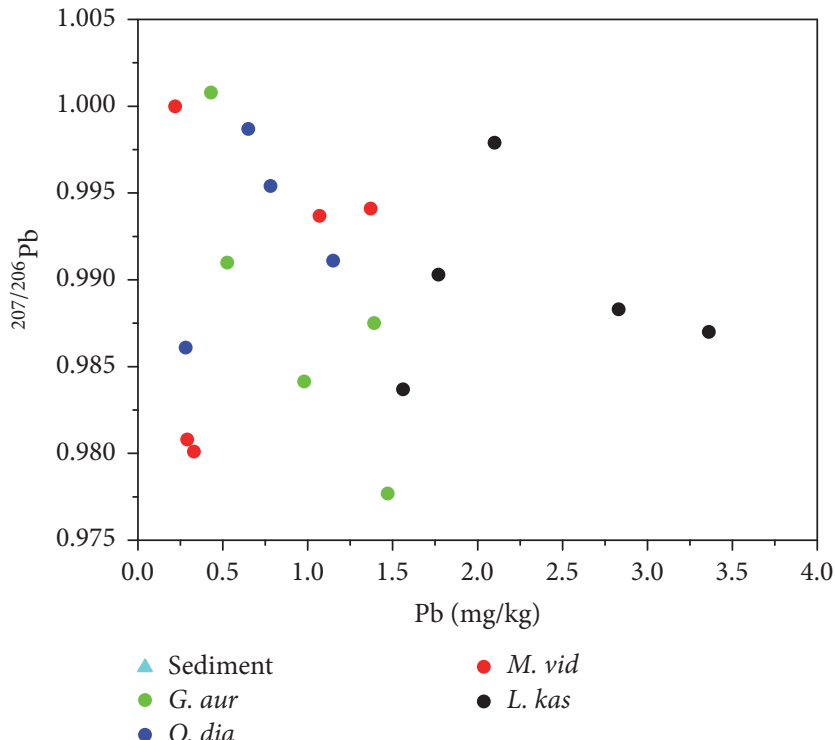

(c)

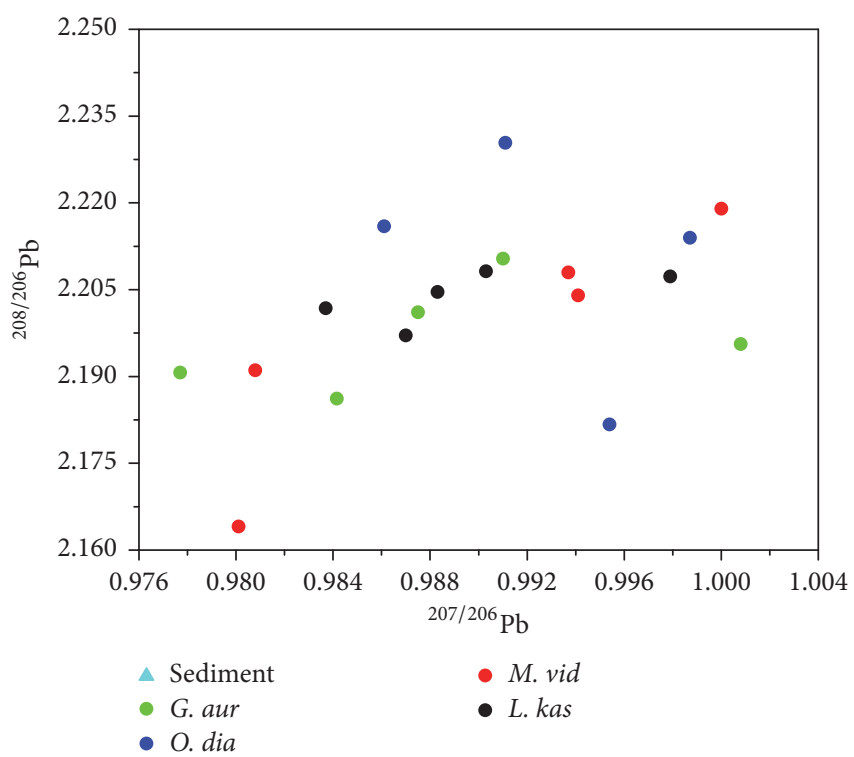

(b)

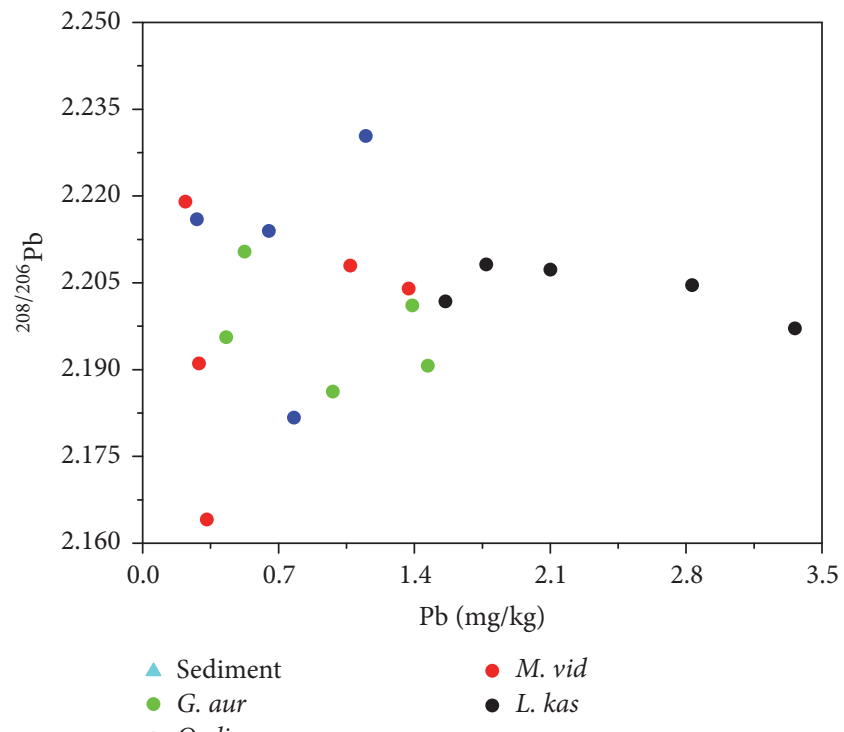

(d)

FIGURE 3: ${ }^{208 / 206} \mathrm{~Pb}$ and ${ }^{207 / 206} \mathrm{~Pb}$ in the four fish species and sediment (Indigo triangle = sediment in South China Sea (from [45]); colored circles $=$ fish species).

$\mathrm{Pb}$ isotopic ratios varied among different tissues in the studied fish, but all showed higher $\mathrm{Pb}$ isotopic ratios than those in their surrounding environments, which indicated the biological fractionation present in these species. Bearing in mind the safe fish consumption levels for humans, the $\mathrm{MSC}_{\mathrm{Zn}}$ in O. dia was below $100 \mathrm{~g}$ fish/day and the $\mathrm{MSC}_{\mathrm{Pb}}$ in $M$. vid and $L$. kas were slightly above $100 \mathrm{~g}$ fish/day, suggesting that this may cause a health risk to human health since consumption would be above the safe threshold.

\section{Conflicts of Interest}

The authors declare that they have no conflicts of interest.

\section{Acknowledgments}

The authors thank the crew of R/V "SHIYAN III" for their help. This work was supported by the National Natural Science Foundation of China (41776088, 40776040, 41576180, 41406213, and J1210050), the Natural Science Foundation of Fujian Province, China (2014J06014), the Program for New Century Excellent Talents in University, and the XMU Training Program of Innovation and Entrepreneurship for Undergraduates (2016X0619, 2016X0624, and 2016X0629). The authors are also grateful to Professor John Hodgkiss of the City University of Hong Kong for assistance with English. 


\section{References}

[1] M. H. Al-Yousuf, M. S. El-Shahawi, and S. M. Al-Ghais, "Trace metals in liver, skin and muscle of Lethrinus lentjan fish species in relation to body length and sex," Science of the Total Environment, vol. 256, no. 2-3, pp. 87-94, 2000.

[2] P. E. Ndimele, M. O. Pedro, J. I. Agboola, K. S. Chukwuka, and A. O. Ekwu, "Heavy metal accumulation in organs of Oreochromis niloticus (Linnaeus, 1758) from industrial effluent-polluted aquatic ecosystem in Lagos, Nigeria," Environmental Modeling \& Assessment, vol. 189, no. 6, pp. 254-269, 2017.

[3] N. S. La Colla, S. E. Botté, A. L. Oliva, and J. E. Marcovecchio, "Tracing $\mathrm{Cr}, \mathrm{Pb}, \mathrm{Fe}$ and $\mathrm{Mn}$ occurrence in the Bahía Blanca estuary through commercial fish species," Chemosphere, vol. 175, pp. 286-293, 2017.

[4] Z. Ren, T.-S. Chon, C. Xia, and F. Li, "The monitoring and assessment of aquatic toxicology," BioMed Research International, vol. 2017, Article ID 9179728, pp. 1-4, 2017.

[5] W. Xu, W. Yan, G. Zhang, J. Li, L. Miao, and W. Huang, "Levels and distribution of heavy metals in atmospheric particular matters over the northern South China Sea," Environmental Science and Pollution Research, vol. 21, no. 14, pp. 8774-8781, 2014.

[6] M. Valko, H. Morris, and M. T. D. Cronin, "Metals, toxicity and oxidative stress," Current Medicinal Chemistry, vol. 12, no. 10, pp. 1161-1208, 2005.

[7] E. M. Alissa and G. A. Ferns, "Heavy metal poisoning and cardiovascular disease," Journal of Toxicology, vol. 2011, Article ID 870125, pp. 1-21, 2011.

[8] M. Canli and G. Atli, "The relationships between heavy metal ( $\mathrm{Cd}, \mathrm{Cr}, \mathrm{Cu}, \mathrm{Fe}, \mathrm{Pb}, \mathrm{Zn}$ ) levels and the size of six Mediterranean fish species," Environmental Pollution, vol. 121, no. 1, pp. 129-136, 2003.

[9] D. Ibrahim, B. Froberg, A. Wolf, and D. E. Rusyniak, "Heavy metal poisoning: clinical presentations and pathophysiology," Clinics in Laboratory Medicine, vol. 26, no. 1, pp. 67-97, 2006.

[10] J.-H. Kim and J.-C. Kang, "Toxic effects on bioaccumulation and hematological parameters of juvenile rockfish Sebastes schlegelii exposed to dietary lead ( $\mathrm{Pb}$ ) and ascorbic acid," Chemosphere, vol. 176, pp. 131-140, 2017.

[11] M. Satoh, H. Koyama, T. Kaji, H. Kito, and C. Tohyama, "Perspectives on cadmium toxicity research," The Tohoku Journal of Experimental Medicine, vol. 196, no. 1, pp. 23-32, 2002.

[12] L. Qi, J. Ma, J. Song et al., "The physiological characteristics of zebra fish (Danio rerio ) based on metabolism and behavior: a new method for the online assessment of cadmium stress," Chemosphere, vol. 184, pp. 1-7, 2017.

[13] T. Zhang, M. Yang, H. Pan et al., "Does time difference of the acetylcholinesterase (AChE) inhibition in different tissues exist? A case study of zebra fish (Danio rerio) exposed to cadmium chloride and deltamethrin," Chemosphere, vol. 168, pp. 908-916, 2017.

[14] U. Çelik and J. Oehlenschläger, "High contents of cadmium, lead, zinc and copper in popular fishery products sold in Turkish supermarkets," Food Control, vol. 18, no. 3, pp. 258-261, 2007.

[15] M. K. Ahmed, N. Shaheen, M. S. Islam et al., "Dietary intake of trace elements from highly consumed cultured fish (Labeo rohita, Pangasius pangasius and Oreochromis mossambicus) and human health risk implications in Bangladesh," Chemosphere, vol. 128, pp. 284-292, 2015.
[16] T. A. Blewett, R. A. Simon, A. J. Turko, and P. A. Wright, "Copper alters hypoxia sensitivity and the behavioural emersion response in the amphibious fish Kryptolebias marmoratus," Aquatic Toxicology, vol. 189, pp. 25-30, 2017.

[17] M. Metian, M. Warnau, T. Chouvelon, F. Pedraza, A. M. Rodriguezy Baena, and P. Bustamante, "Trace element bioaccumulation in reef fish from New Caledonia: Influence of trophic groups and risk assessment for consumers," Marine Environmental Research, vol. 87-88, pp. 26-36, 2013.

[18] R. Alquezar, S. J. Markich, and D. J. Booth, "Metal accumulation in the smooth toadfish, Tetractenos glaber, in estuaries around Sydney, Australia," Environmental Pollution, vol. 142, no. 1, pp. 123-131, 2006.

[19] O. A. H. Jones, D. A. Dias, D. L. Callahan, K. A. Kouremenos, D. J. Beale, and U. Roessner, "The use of metabolomics in the study of metals in biological systems," Metallomics, vol. 7, no. 1, pp. 29-38, 2015.

[20] V. F. Marijić and B. Raspor, "Metallothionein in intestine of red mullet, Mullus barbatus as a biomarker of copper exposure in the coastal marine areas," Marine Pollution Bulletin, vol. 54, no. 7, pp. 935-940, 2007.

[21] I. S. Rabitto, J. R. M. Alves Costa, H. C. Silva De Assis et al., "Effects of dietary $\mathrm{Pb}(\mathrm{II})$ and tributyltin on neotropical fish, Hoplias malabaricus: histopathological and biochemical findings," Ecotoxicology and Environmental Safety, vol. 60, no. 2, pp. 147-156, 2005.

[22] G.-Y. Huang, G.-G. Ying, Y.-Q. Liang, S.-S. Liu, and Y.-S. Liu, "Expression patterns of metallothionein, cytochrome P450 $1 \mathrm{~A}$ and vitellogenin genes in western mosquitofish (Gambusia affinis) in response to heavy metals," Ecotoxicology and Environmental Safety, vol. 105, no. 1, pp. 97-102, 2014.

[23] A. Lange, O. Ausseil, and H. Segner, "Alterations of tissue glutathione levels and metallothionein $\mathrm{mRNA}$ in rainbow trout during single and combined exposure to cadmium and zinc," Comparative Biochemistry and Physiology - C Toxicology and Pharmacology, vol. 131, no. 3, pp. 231-243, 2002.

[24] M. Ahmed, T. Ahmad, M. Liaquat, K. S. Abbasi, I. B. A. Farid, and M. Jahangir, "Tissue specific metal characterization of selected fish species in Pakistan," Environmental Modeling \& Assessment, vol. 188, no. 4, article 212, pp. 211-220, 2016.

[25] D. Büsselberg and A.-M. Florea, "Metals and breast cancer: risk factors or healing agents?" Journal of Toxicology, vol. 2011, Article ID 159619, 2011.

[26] $\mathrm{H}$. Cheng and $\mathrm{Y} . \mathrm{Hu}$, "Lead $(\mathrm{Pb})$ isotopic fingerprinting and its applications in lead pollution studies in China: a review," Environmental Pollution, vol. 158, no. 5, pp. 1134-1146, 2010.

[27] A. Bollhöfer and K. J. R. Rosman, "Isotopic source signatures for atmospheric lead: the Southern Hemisphere," Geochimica et Cosmochimica Acta, vol. 64, no. 19, pp. 3251-3262, 2000.

[28] A. Bollhöfer and K. J. R. Rosman, "Isotopic source signatures for atmospheric lead: the Northern Hemisphere," Geochimica et Cosmochimica Acta, vol. 65, no. 11, pp. 1727-1740, 2001.

[29] F. Marcantonio, A. Zimmerman, Y. Xu, and E. Canuel, "A Pb isotope record of mid-Atlantic US atmospheric $\mathrm{Pb}$ emissions in Chesapeake Bay sediments," Marine Chemistry, vol. 77, no. 2-3, pp. 123-132, 2002.

[30] M. Choi, J. Park, D. Cho, D. Jang, M. Kim, and J. Choi, “Tracing metal sources in core sediments of the artificial lake An-Dong, Korea: concentration and metal association," Science of the Total Environment, vol. 527-528, pp. 384-392, 2015.

[31] Y. Xu, Q. Sun, L. Yi et al., "The source of natural and anthropogenic heavy metals in the sediments of the Minjiang River 
Estuary (SE China): Implications for historical pollution," Science of the Total Environment, vol. 493, pp. 729-736, 2014.

[32] H. Nakata, S. M. M. Nakayama, J. Yabe et al., "Reliability of stable $\mathrm{Pb}$ isotopes to identify $\mathrm{Pb}$ sources and verifying biological fractionation of $\mathrm{Pb}$ isotopes in goats and chickens," Environmental Pollution, vol. 208, pp. 395-403, 2016.

[33] F. Svanberg, R. Mateo, L. Hillström et al., "Lead isotopes and lead shot ingestion in the globally threatened marbled teal (Marmaronetta angustirostris) and white-headed duck (Oxyura leucocephala)," Science of the Total Environment, vol. 370, no. 23, pp. 416-424, 2006.

[34] M. Martinez-Haro, M. A. Taggart, R. R. C. Martín-Doimeadiós, A. J. Green, and R. Mateo, "Identifying sources of $\mathrm{Pb}$ exposure in waterbirds and effects on porphyrin metabolism using noninvasive fecal sampling," Environmental Science \& Technology, vol. 45, no. 14, pp. 6153-6159, 2011.

[35] F. Moberg and C. Folke, "Ecological goods and services of coral reef ecosystems," Ecological Economics, vol. 29, no. 2, pp. 215$233,1999$.

[36] X.-Z. Wang, Y.-Y. Jiao, R. Wang, M.-J. Hu, Q.-S. Meng, and F.Y. Tan, "Engineering characteristics of the calcareous sand in Nansha Islands, South China Sea," Engineering Geology, vol. 120, no. 1-4, pp. 40-47, 2011.

[37] C.-Q. Zhu, Y. Qin, Q.-S. Meng, X.-Z. Wang, and R. Wang, "Formation and sedimentary evolution characteristics of Yongshu Atoll in the South China Sea Islands," Ocean Engineering, vol. 84, pp. 61-66, 2014.

[38] J.-L. Liu, X.-R. Xu, Z.-H. Ding et al., "Heavy metals in wild marine fish from South China Sea: levels, tissue- and speciesspecific accumulation and potential risk to humans," Ecotoxicology, vol. 24, no. 7-8, pp. 1583-1592, 2015.

[39] Y.-G. Gu, Q. Lin, H.-H. Huang, L.-G. Wang, J.-J. Ning, and F.Y. Du, "Heavy metals in fish tissues/stomach contents in four marine wild commercially valuable fish species from the western continental shelf of South China Sea," Marine Pollution Bulletin, 2016.

[40] C. C. Ip, X. D. Li, G. Zhang, C. S. Wong, and W. L. Zhang, "Heavy metal and $\mathrm{Pb}$ isotopic compositions of aquatic organisms in the Pearl River Estuary, South China," Environmental pollution, vol. 138, no. 3, pp. 494-504, 2005.

[41] A. Velusamy, P. Satheesh Kumar, A. Ram, and S. Chinnadurai, "Bioaccumulation of heavy metals in commercially important marine fishes from Mumbai Harbor, India," Marine Pollution Bulletin, vol. 81, no. 1, pp. 218-224, 2014.

[42] C. L. Voigt, C. P. da Silva, H. B. Doria, M. A. F. Randi, C. A. de Oliveira Ribeiro, and S. X. de Campos, "Bioconcentration and bioaccumulation of metal in freshwater Neotropical fish Geophagus brasiliensis," Environmental Science and Pollution Research, vol. 22, no. 11, pp. 8242-8252, 2015.

[43] Y. Saygi and S. A. Yiğit, "Assessment of metal concentrations in two cyprinid fish species (Leuciscus cephalus and Tinca tinca) captured from Yeniçaǧa Lake, Turkey," Bulletin of Environmental Contamination and Toxicology, vol. 89, no. 1, pp. 86-90, 2012.

[44] H. Gan, J. Lin, K. Liang, and Z. Xia, "Selected trace metals (As, $\mathrm{Cd}$ and $\mathrm{Hg}$ ) distribution and contamination in the coastal wetland sediment of the northern Beibu Gulf, South China Sea," Marine Pollution Bulletin, vol. 66, no. 1-2, pp. 252-258, 2013.

[45] L. Zhu, L. Guo, Z. Gao et al., "Source and distribution of lead in the surface sediments from the South China Sea as derived from $\mathrm{Pb}$ isotopes," Marine Pollution Bulletin, vol. 60, no. 11, pp. 2144-2153, 2010.
[46] M. H. Cai, J. Lin, Q. Q. Hong, Y. Wang, and M. G. Cai, “Content and distribution of trace metals in surface sediments from the northern Bering Sea, Chukchi Sea and adjacent Arctic areas," Marine Pollution Bulletin, vol. 63, no. 5-12, pp. 523-527, 2011.

[47] R. Shi, J. Lin, Y. Ye, Y. Ma, and M. Cai, “The level and bioaccumulation of $\mathrm{Cd}, \mathrm{Cu}, \mathrm{Cr}$ and $\mathrm{Zn}$ in benthopelagic species from the Bering Sea," Acta Oceanologica Sinica, vol. 34, no. 6, pp. 2125, 2015.

[48] FAO/WHO, "Evaluation of certain food additives and contaminants," Twenty-second Report of the Joint FAO/WHO expert committee on food additives, Joint FAO/WHO Expert Committee on Food Additives, Rome, Italy, 1982.

[49] FAO/WHO, "Evaluation of certain food additives and contaminants," Thirty-Third Report of The Joint FAO/WHO Expert Committee on Food Additives, World Health Organization, Geneva, 1989.

[50] FAO/WHO, "Evaluation of certain food additives and contaminants," Forty-first report of the Joint FAO/WHO Expert Committee on Food Additives, World Health Organization Technical Report, 1993.

[51] J. J. R. Frausto da Silva and R. Williams, The Biological Chemistry of The Elements: The Inorganic Chemistry of Life, Clarendon Press, 2001.

[52] I. Bertini, H. B. Gray, E. I. Stiefel et al., Biological Inorganic Chemistry: Structure and Reactivity, Biological inorganic chemistry, structure and reactivity, 2007.

[53] J. M. Neff, "Bioaccumulation in Marine Organisms," Bioaccumulation in Marine Organisms, pp. 319-437, 2002.

[54] M. Olgunoglu, E. Artar, and İ. Olgunoglu, "comparison of heavy metal levels in muscle and gills of four benthic fish species from the Northeastern Mediterranean sea," Polish Journal of Environmental Studies, vol. 24, pp. 1743-1748, 2015.

[55] A. T. Khan and J. S. Weis, "Bioaccumulation of heavy metals in two populations of mummichog (Fundulus heteroclitus)," Bulletin of Environmental Contamination and Toxicology, vol. 51, no. 1, pp. 1-5, 1993.

[56] A. R. Oğuz and A. Yeltekin, "Metal levels in the liver, muscle, gill, intestine, and gonad of Lake Van Fish (Chalcalburnus tarichi) with abnormal gonad," Biological Trace Element Research, vol. 159, no. 1-3, pp. 219-223, 2014.

[57] S. F. Perry and P. Laurent, Environmental Effects on Fish Gill Structure and Function, Springer Netherlands, 1993.

[58] A. Mauceri, M. C. Fossi, C. Leonzio et al., "Stress factors in the gills of Liza aurata (Perciformes, Mugilidae) living in polluted environments," Italian Journal of Zoology, vol. 72, no. 4, pp. 285292, 2005.

[59] M. O. Özkaya, M. NazIroğlu, C. Barak, and M. Berkkanoglu, "Effects of multivitamin/mineral supplementation on trace element levels in serum and follicular fluid of women undergoing in vitro fertilization (IVF)," Biological Trace Element Research, vol. 139, no. 1, pp. 1-9, 2011.

[60] M. P. Olgunoğlu, İ. A. Olgunoğlu, and Y. K. Bayhan, "Heavy metal concentrations ( $\mathrm{Cd}, \mathrm{Pb}, \mathrm{Cu}, \mathrm{Zn}, \mathrm{Fe})$ in Giant Red Shrimp (Aristaeomorpha foliacea Risso 1827) from the Mediterranean sea," Polish Journal of Environmental Studies, vol. 24, no. 2, pp. 631-635, 2016.

[61] M. D. Ptashynski, R. M. Pedlar, R. E. Evans, C. L. Baron, and J. F. Klaverkamp, "Toxicology of dietary nickel in lake whitefish (Coregonus clupeaformis)," Aquatic Toxicology, vol. 58, no. 3-4, pp. 229-247, 2002. 
[62] E. Baysoy, G. Atli, and M. Canli, "The effects of salinity and salinity+metal (chromium and lead) exposure on atpase activity in the gill and intestine of tilapia oreochromis niloticus," Archives of Environmental Contamination and Toxicology, vol. 64, no. 2, pp. 291-300, 2013.

[63] D. F. Woodward, A. M. Farag, H. L. Bergman et al., "Metalscontaminated benthic invertebrates in the Clark Fork River Mont," Canadian Journal of Fisheries \& Aquatic Sciences, vol. 52, no. 9, pp. 1994-2004, 1994.

[64] A. Qiu, C. N. Glover, and C. Hogstrand, "Regulation of branchial zinc uptake by $1 \alpha, 25-(\mathrm{OH}) 2 \mathrm{D} 3$ in rainbow trout and associated changes in expression of ZIP1 and ECaC," Aquatic Toxicology, vol. 84, no. 2, pp. 142-152, 2007.

[65] R. W. M. Kwong, Dietary Divalent Metal Uptake And Interactions in Freshwater Fish: Implications for Metal Toxicity, Dietary Exposure, 2011.

[66] J. L. Domingo, "Heavy metals in marine species from the Tarragona coast, Spain," Journal of Environmental Science Health Part A Environmental Science Engineering Toxic Hazardous Substance Control, vol. A27, no. 7, pp. 1939-1948, 1992.

[67] J. Liu, R. A. Goyer, and M. P. Waalkes, "Toxic effects of metals," Casarett and Doull's Toxicology - The Basic Science of Poisons, 2008.

[68] K. M. El-Moselhy, A. Othman, H. Abd El-Azem, and M. ElMetwally, "Bioaccumulation of heavy metals in some tissues of fish in the Red Sea, Egypt," Egyptian Journal of Basic and Applied Sciences, vol. 1, no. 2, pp. 97-105, 2014.

[69] FAO, "Fish and fishery products: Food balance sheets by main groups of fish species and fish nutritional factors, Food and Agriculture Organization of the United Nations, vol. 3, 2008”. 

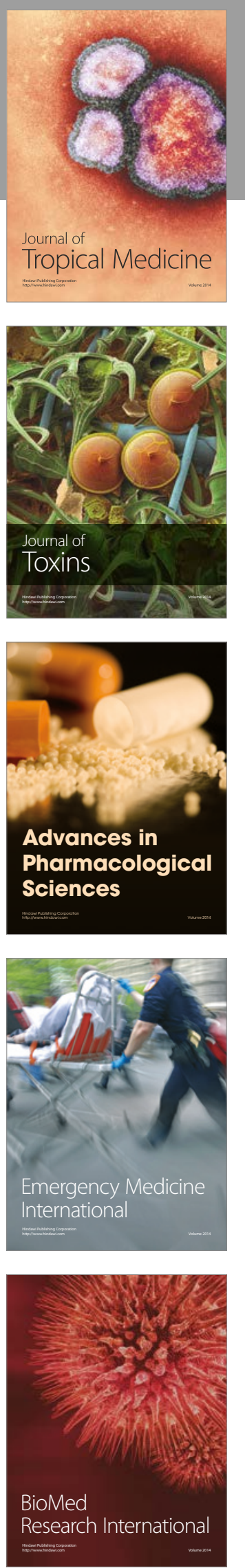
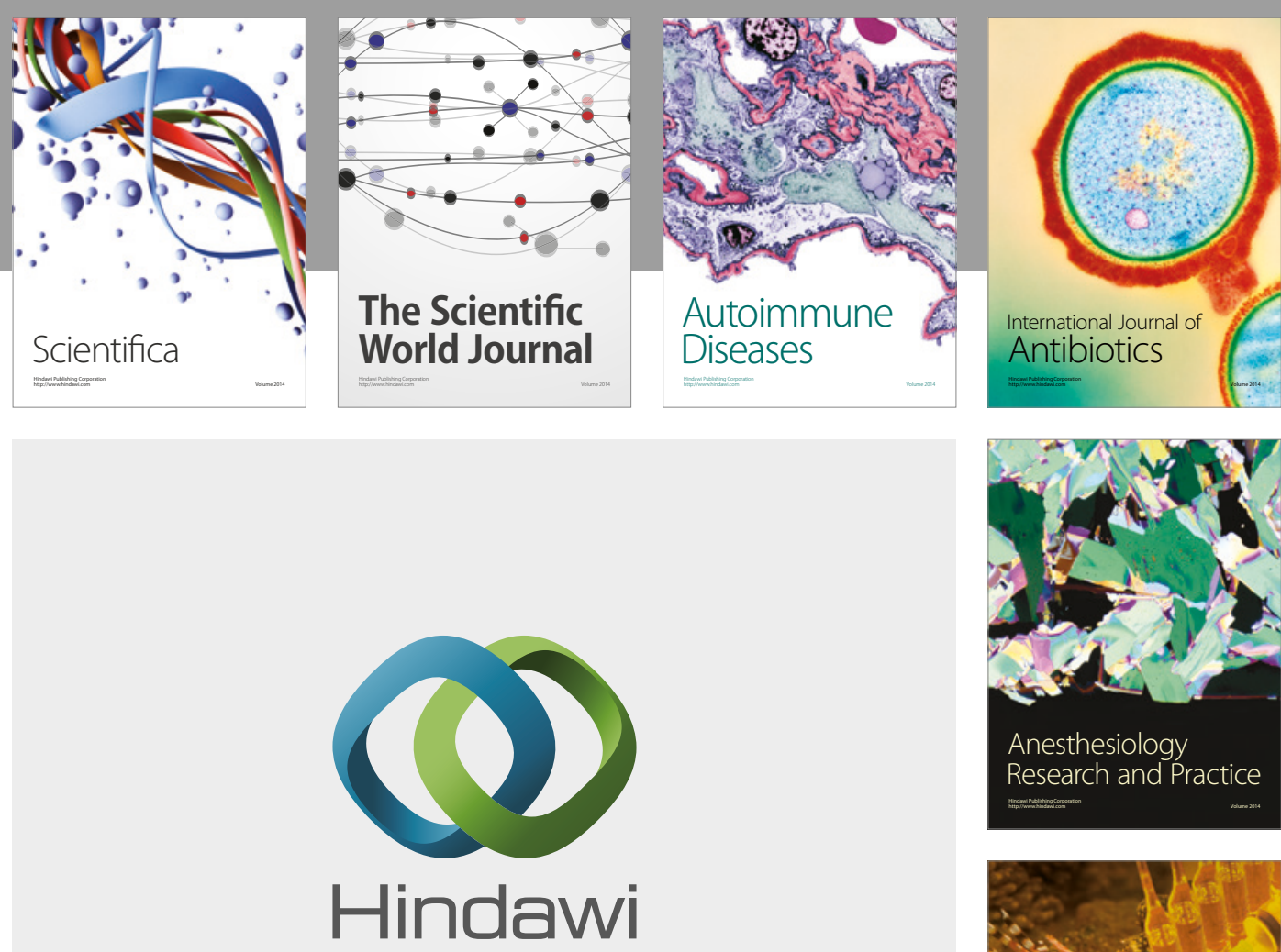

Submit your manuscripts at

https://www.hindawi.com
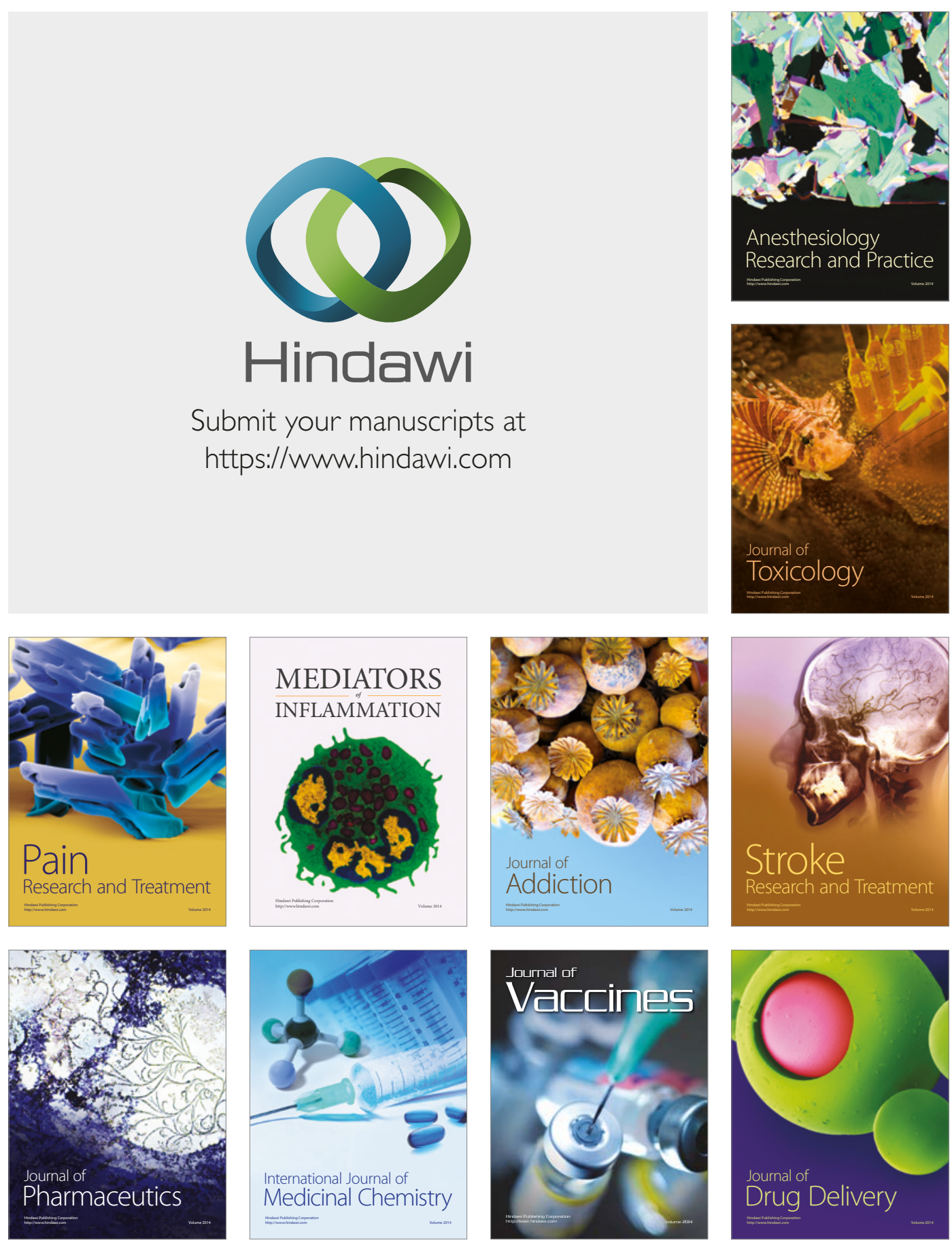